refer such cases to those institutions most suitable for the treatment of the various complaints; and when it is re$\mathrm{m} \leftarrow$ mbered that there are about 4000 collectors, in as many workshops, having the right to receive letters of recommendation to any of the 120 participating institutions, it will help to indicate the magnitude of our work, apart altogether from the organisation necessary to collect the contributions of the working men and women of such a city as London. Mr. Hamilton Hoare, in stating that 18s. out of every $f l$ has becn contiibated by the working classes, is certainly within the mark, and the sugnestion that the working classes do not sub cribe to the street collection we know to be groundl+ss. During the past year over $£ 7000$ has reached us direct from the workshops out of a total of about $\$ 9500$, and if a considerable proportion of the $£ 512 s$. collected at Hyde-park-corner was from other friends than working people, we certainly may claim that the $£ 94 \mathrm{~s}$. $4 \frac{1}{2} \mathrm{~d}$. collected in Billingsgate-market, the $£ 90 s$. $1 d$. on Stepney-green, the \&8 $1 s$. $3 \frac{1}{2} d$. at the Whitechapel Railway-station, and the $£ 6$ 18s. $10 \frac{1}{2} d$. collected at the gates of the London Hospital, were contributed in the main by men and women whose sympathies we have desired to secure.

You say that the Hospital Saturday Fund " has every year received proportionately less from the workshops and more from street collections and other adventitious aids." The fact is, Sir, that our books, which are open to inspection, show clearly that the Fund received more from adventitious aid during the first year of its existence than in any subsequent year. That we are able-this, the tenth year of our work - to distribute to the various hospitals and dispensaries of London $£ 1000$ more than last year, and doubl th amo int of the award of either the first, second, or third years of the existence of the Fund, is a sufficient answer to the statement that " the working classes of London are holding aloof from the Hospital Saturday Fund." The statement that the Council of the Hospital Saturday Fand "bas tried to take funds received specially for one hospital, and to apply them to the general purposes of this Fund," is absolutely unfousded, and in the only instance given - that of the Victoria Hospital for Children, - so far from desiring to interfere with the action of the Local Committee, the Board of Delegatts expressed their hearty sympathy and congratulation, and instructed me to write, in reply to the Honorary Secretary of the Church Parade and Demonstration Commitree, intimating that such effort would not in any way affect the award by this Fund.

I will only add that the absorption of this Fund by the Hospital Sunday Fund, as suggested, can only mean the annihilation of this movement, for certainly there can be no organisation less suited to reach the workshops of London, and to secure the confidence and co-operation of the working classes, than the organisation by which the Hospital Sunday Fusd is governed.-I am, Sir, yours obediently,

ROBERT FREWER,

$$
\text { Nov, 26th, 1E83. Secretary of the Hospital Saturday Fund. }
$$

We insert the above letter in all fairness at the request of Mr. Frewer, who does not consider that the summary in our issue of last week sufficiently represented his view of the matter.-ED, $\mathrm{L}$.

\section{CHOLERA ON BOARD SHIPS AT SEA.}

\section{To the Editor of THE LANCET.}

SIR,-In a recent leader entitled "Pettenkofer on Cholera and Quarantine" in the columns of a contemporary the following sentence $a$ propos of the improbability of this disease being conveyed from Bombay to Egypt occurs: "There is no instance of the conveyance of the disease by Indian steamers to Australia, the Cape, or even to the Mauritius, though the majority of the passengers by the last line are coolies." As regards the Cape and Australia this is correct, probably owing as much to the character of the ships and passengers and the duration of the voyage as to the existence of quarautine, which, unless when the disease broke out on board, could not possibly be needed. As regards Mauritius and the coolies such is not the case, as the following extrac's from Dr. Gordon's careful notes clearly show :-

"Into Mauritius it was carried in $\mathbf{1 8 5 4}$ by coolies from India by the ship Sultang. Into Mauritius in 1856 by the ships Hyderee and Futtah Mronbareh. These vessels gene- rally arrived at Port Louis on the 5th and 8th of January having coolies on board. Deaths by cholera had occurred in both during the voyage. On arrival the coolies were landed at Gabriel Island. A Creole on that island, having been attacked, was landed at Port Lou is by the s.s. Victoria, and the crew of the vessel being permitted to ramble through the town, cholera broke out and sacificed thourands of victims. Again into Mauritius in 1859 by the Topaz from Calcutta."

I will not enter on the subject of the speedy disappearance of cholera on board ships at sea, which as a rule is correct, and is at least partially explicable by the facilities existing for immediate removal of the stools; nor would I have troubled you to insert this letter did I not feel the urgent neces. sity of at once contradicting any erroneous statement connected with cholera when supported by the great name of Pettenkofer. The endemic theory as applied to Egypt may possibly be correct, but it certainly will not eventually he benefited by ignorance of facts tending in an opposite direction.

Welbeck-street. I am, Sir, yours obediently,

D. H. Cullimore, M.D.

\section{LIVERPOOL. \\ (From our own Correspondent.)}

\section{SOL.ILID LIVERPOOL.}

Trie articles entitled "Squalid Liverpool," alluded to in THE LANCET of the 24th November, have been published in pamphlet form. They are stated to be the joint work of " a well-known city councillor, a prominent local physician, and a member of the Daily Post literary staff." Mr. A. B. Forwood, formerly chairman of the Health Committee, has also published a pamphlet on "Labourers' D wellings." The facts disclosed in each, though unknown to many of the general public, especially of the upper class, are perfectly familiar to most members of the profession. Many who are now well established in large and lucrative practice have worked as dispensary house surgeons or parochial medical rfficers in squalid Liverpool, and have been succetded by others who have done, and are doing, good useful work amidst the most miserable surroundings, and under the most unfavourable circumstances.

Though it is easy to point ont the evils attendant upon the miserable dwellings in which the working classes are housed, and to suggest a remedy, there remains an evil for which no cure bas been suggested. Supposing that after we have spent $£ 200,000$, as has been proposed, in providing dwellings for the better class of labourers, and that squalid Liverpool becomes a thing of the past, what is to be done with that large class who will make squalid any houses in which they may be placed? What can landlords and property owners do with tenants who, when the spirit moves them, tear up the flooring and stairs for firewood? This is a question which social reformers have not answered.

\section{THE SOCIAL EVIL IN LIVERPOOL,}

From the annual report of the head constable, just publisbed, it appears that there are within the borough 495 brothels and 1196 prostitutes, this latter number being exclusive of those known to be in gaol. Another table in the same report gives the number of cases of prostitutes procreded against under the Vagrant Act during the year as 3415. A third table gives the number of prostitutes summarily convicted for being disorderly in the streets as 2060 . It also appears that twelve persons were prnceeded against for keeping disorderly houses, of whom six were discbarged and six convicted. This fact, taken in conjunction with the total number of brothels, furnishes a most singular commentary on the present state of the law which makes it an indictable offence for any person to keep a brothel. Captain Bowen states: "Whenever young fereales or the children of the inmates are found in brothels, prompt action is taken. It is much to be regietted that the law confers no power on the police as to visiting these houses."

$$
\text { MR. PUZEY S CASE OF FRACTURED PATELLA. }
$$

The subsequent course of this case (detailed in a previous letter) speaks well for the patient's good constitution and for the value of the Listerian treatment. With the exception of the usual slight rise $\left(100^{\circ}\right)$ a few hours after the operation, the temperature has been subnormal. There has been no 